MUDRA: Journal of Finance and Accounting, Volume 4, Issue 2, July-December 2017, pp. 127-144

doi: 10.17492/mudra.v4i02.11450

\title{
State-wise Assessment of Banking Frauds in India: A Study of Trends in $21^{\text {st }}$ Century
}

\author{
Anju Rohilla*
}

\begin{abstract}
Fraud costs an arm and a leg to a bank. The bank has to face reputational, monetary loss as well as loss of customer faith. Increasing number of bank frauds arouses the interest of research to examine the current picture of the banking frauds prevailing in the states of Indian Economy. The study is extended over a period of 10 years i.e. from 2007-2016.The analysis has been done to show the trend of frauds in the $21^{\text {st }}$ century. RTI is used as the primary sources of data collection and Lok Sabha starred and unstarred questions are used as secondary sources of data. The methodologies adopted for analysing the trend consists of descriptive statistics and the graphical presentation. The finding of the study shows an increasing trend in the number and amount of banking frauds in the states of India. If we go by the number and amount, Maharashtra is the most affected state of the economy but if we talk about average amount involved in fraud, Chandigarh and West Bengal fall among the most affected states of India. The study signifies the importance of strengthening the mechanism of preventing banking fraud. The government of India and RBI are recommended to frame the judicial policies for curbing the banking frauds as slow and weak judicial procedures/ prosecution provide a platform to fraudsters and delay in fraud detection provides an escape route.
\end{abstract}

Keywords: Fraud; Banking frauds; PSBs; Trend, KYC, EWS, RFA.

\subsection{Introduction}

On $21^{\text {st }}$ Oct 2016, Indian economy suddenly grabbed the attention of the global media when it was disclosed that about 3.2 million $^{1}$ debit cards were exposed to the multiple bank cyber fraud by an unknown cyber hacker. "Multiple Bank Cyber Hit: What happened; how it happened and what happens now?" were the common headlines of newspaper, articles and press release.

*Research Scholar, Bhagat Phool Singh Mahila Vishwavidyalan, Sonipat, Haryana, India. (Email id: anju.rohilla.snp@gmail.com) 
It was the biggest cyber-attack on the Indian banking sector in the history of Indian economy. Unknown hackers broke into the system of the Hitachi Payment Services which provides the services of ATMs, Point of Sale, and many other services; and obtained the necessary information about the debit cards and used them in China and US to cheat the cardholders. The biggest cyber-attack came into notice via the complaint of the banks and customer. On $5^{\text {th }}$ Sep 2016, few banks came across fraudulent transactions in which debit cards were used in China and US when the customers were actually in India. The same transactions were also detected by the cardholders and they complained to the bank about it. Subsequently, the banks complained NPCI (National Payment Corporation of India, NPCI). NPCI found a malware-induced Security Breach in the systems of Hitachi Payment Services. The report of investigation revealed that breach occurred only in the ATMs of the particular private bank. NPCI reported ${ }^{2}$ that around 641 customers across 19 banks lost Rs $1.3 \mathrm{cr}$. as a result of the fraudulent transaction on their debit card.

Anyway, malware attack was detected in time and was duly informed to the RBI. As per an Axis bank official, the bank's internal monitoring mechanism identified such a threat recently and all steps have been undertaken to neutralise the same. State Bank of India has blocked 6 lakhs debit cards and RBI has instructed the banks to issue chip base and strip base Debit cards to overcome the threat of cyber-attacks. RBI also instructed the banks to draft the policy against the cyber-crime and prepare a Cyber Crisis Management Plan.

Coming back home, Banks are considered as the lifeline of the economy (Jain, 2010) and play a vital role in activating and sustaining economic growth, especially in developing countries like India (Mundra, 2015). A liberalised and truly global Indian economy is witnessing an exponential growth in the financial system of an economy (Kaveri, 2014). Indian economy is the fastest developing economy but this growth is accomplished with pitfalls in the form of increased frauds, a majority of which are in the form of cyber-crime (Kant, 2016). It is the irony of the universe that there are two sides of the coin, on one side where the technology plays the role of the biggest driver in achieving the financial growth, on the other side, it poses most serious challenges to the financial system (Kant, 2016).

In a report 'Nation on Occupational Fraud and Abuse by Association of Certified Fraud Examiners (ACFE)', the Deputy Governor said that the amount involved in the frauds report in the Indian banking sector has been increased more than four times to Rs 8646 Cr. in FY 2012-13 from Rs. 2038 cr. in FY 2009-10. The frauds in the financial institution like banks pose a momentous risk and can be the foundation of the 
pecuniary and reputational indemnity to the whole economy. $94 \%$ of the people believe that the frauds have become more complicated than earlier (KPMG, 2012).

Frauds can be described as a conscious premeditated action of a person or group of persons with the intention of altering the truth and/or act for selfish, personal, monetary gains (Nzotta, 1999). Silverstone \& Sheetz (2004) provided the broader definition of fraud taking into the view that individual \& organizations commit fraudulent acts to obtain money, property or services purposely to avoid the payment or the loss of money/ services and to take business advantage or for personal security. The term fraud has not been defined in the Indian Panel Code but in the Indian Contract Act, 1872 Fraud has been defined in the sections 17 (Ghosh \& Bagheri, 2006).

As per Indian Contract Act, 1872, fraud is defined as follows: Fraud means and includes any of the following acts committed by a party to a contract, or with his connivance, or by his agent, with intent to deceive another party thereto or his agent, or to induce him to enter the contract:

- The suggestion, as to a fact, of that which is not true, by one who does not believe it to be true;

- The active concealment of a fact by one having knowledge or belief of the fact;

- A promise made without any intention of performing it;

- Any other act fitted to deceive;

- Any such act or omission as the law specially declares to be fraudulent.

In the same manner, banking fraud is defined as the use of the potentially illegal means to obtain money, assets or the other owned or held by the financial institution (Banks), or to obtain money from depositors by fraudulently posing as a bank or other financial institution (Ghosh \& Bagheri, 2006). Frauds result in the largest single cause of bank failure and also impact on banking operations (Ahmed, Madawaki \& Usman, 2014).

This research paper aims to study the trend of banking frauds in the states of the Indian economy in the $21^{\text {st }}$ century. The researcher is dedicated towards making several contributions to the banking fraud literature. Firstly, we have collected the information regarding the frauds and developed an understanding regarding the frauds in the banking sector. Secondly, we analyse the trends of banking frauds in states of India both Number-wise and Amount-wise. Moreover, we will identify which state is highly affected and least affected by banking frauds. 
The remainder of the study into five sections. Section 2 reviews the relevant available literature. Section 3 defines the objectives of the study. Section 4 presents the research design. Section 5 analyses the results and section 6 concludes the study.

\subsection{Literature review}

The literature is collected through the various research papers, articles, books and the published reports related to banking fraud which reveals that very less work has been carried out in the area of banking fraud. The findings of studies described the different kinds of the frauds prevailing in the banking sector and the causes of fraud.

For a long period of time, the existence of financial fraud has been a subject of concern (Sabale, 2011). The ACFE report has mentioned that as much as frauds are concerned, the banking and the financial institution are the most victimized sector. Fagbemi, 1989 defines the fraud as the act of depriving a person dishonestly of something which is his or something to which he is or would but for the perpetration of fraud, is entitled. Fraud covers the criminal offences that involve the use of the deception for personal gain at the detriment or the loss of another person. It includes theft, bribery, forgery, embezzlement, misappropriation, conspiracy, collusion, money laundering, extortion and concealment of material facts (Theft Act 1978 ${ }^{3}$; Fraud Act $2006^{4}$; Charted Institute of Management Accountants, $2008^{5}$ ). As per Albercht (1996), the fraud consists of mainly three components: theft, concealment and conversion banking. Fraud is defined as the use of the potentially illegal means to obtain money, assets or the other owned or held by the financial institution /Banks (Nabhan \& Hindi, 2009), or to obtain money from depositors by fraudulently posing as a bank or other financial institution (Ghosh \& Bagheri, 2006). Cressey (1953) provides the Fraud Triangle Theory which defines the behaviour of the fraudsters and explains the three reasons behind any frauds. First Pressure, Second, Opportunity and last is Rationalization. Fraud occurs due to ignorance, situational pressure and permissive attitudes (Kundu \& Rao, 2014).

As per the Deloitte, India Banking Fraud Survey 2015, the major reason behind the increased number of fraud incidents is the lack of oversight line by Managers and Senior Manager on the deviations from the existing process and the controlling techniques. Khanna \& Arora (2009) survey 253 banks and concluded that the lack of training, overburdened staff, competition, low compliance level are the main reasons for the bank's frauds. Frauds have negatively affected the bank and its customer both. It results into financial loss such as a decrease in the value of shareholders fund and the bank's capital and customer money as well as the non- monetary loss to bank such as loss of goodwill/ reputation and loss of confidence in the bank (Chiezey \& Onu, 2013). No 
new frauds are found, just the way of committing the frauds have changed (Singh, 2013). The fraudsters are becoming smart and very intelligent; they staggered the world by using the new and advanced modus-operandi (Bhutto, 2011). Due to the technology upgradation and technological complexity fraud detection and prevention never be a piece of cake (Willson, 2006).

Detection and prevention of frauds for banks is a challenging task and these difficulties can often be worse by the political, regulatory, and institutional frameworks that are in place (Akelola, 2012). According to Chakraborty (2013), the bank related frauds are categorised under three subheads - technology related, KYC related and advance related. The new private banks and the foreign banks dominate in the terms of the technology related fraud as they deliver more technology-related services in the Indian banking sector (Soni \& Soni, 2013). KYC Frauds consists of gaining access to the customer account identity and information and using it illegally. Use of stolen identities is also in trend (Hartmann- Wendels et al., 2009). As per the report of DNA ${ }^{6}$, the ICICI bank held accountable for nearly $65 \%$ of the reported fraud cases (3304 out 5319 cases in FY 2010-11) which were related to phishing and KYC whereas advance related frauds accounted for a major portion of the total amount involved in frauds i.e. 64\% (ASSOCHAM, 2015). The profile of the fraudster is classified into following categories: Management of the banks; Insider; Outsider; Insider in collusion with an outsider (Owolabi, 2010). According to the report Insider Fraud in Financial Services of Homeland Security Advance Research Agency Insider fraud is committed by a malicious insider which is a current or former employee, contractor, or other business partner, who has or had authorized access to organization's network, system, or data and intentionally exceeded or misused that access in a manner that negatively affected the confidentiality, integrity or availability of the organization's information or information systems. According to the study conducted by Idolor (2010), there is an equal level of staff involvement in initiation and execution of fraud with the active concealment of fraud. Overwhelming personal debt, revenge, poor internal control, readily available technology, and opportunity were the most common reasons for the employee fraud (Haugen \& Selin, 1999). The banking frauds can't be completely wiped out but the bank can secure them and the customer from unknown threats by a certain level of preparedness (Bhasin, 2015). Providing a training program for the banking employee is most important in fraud management as the Barnes, 1995 has focused on the training of the employees. As quality training not only develops job-related skill but also boosts the performance of the employee, update their knowledge (Ganesh and Raghurama, 2008) and helps in understanding the banking procedures (Barnes, 1995). 
132 | MUDRA: Journal of Finance and Accounting, Volume 4, Issue 2, Jul-Dec 2017

\subsection{Objectives and scope}

The main objective of the research work is to make a study of banking frauds in India. More specifically the objectives of the research are:

- To assess the trends of State-wise frauds in public sector banks of India in 'Absolute Figure';

- To identify the state most affected by the banking fraud.

The study undertaken is confined to data compiled from various secondary sources. It covers only the aspect of the total number of fraud and amount involved during the ten years period from 2007 to 2016 in the states of Indian economy.

\subsection{Limitations of study}

Due to constraints of time and resources, the study is likely to suffer from following limitations. Some of these are mentioned here so that findings of the study may be understood in a proper perspective:

- The total number of banks in the Indian economy is so large and the data is so varied and diverse that it needs a lot of time and resources to analyse them all.

- As the study uses cyber security secondary data, the possibility of unauthorised information cannot be avoided.

\subsection{Research design}

Research Design is a conceptual structure within which research provide and designing of research comprises data collection and data analysis.

\subsection{Data collection}

The study of bank frauds is based on the secondary data compiled from the following sources:

- RTI is used as the primary source of data. RTI (Right to Information) could serve as the only method and with for the collection of data. The information of frauds from the year 2007-2016 is collected by filling RTI on RBI and Individual banks.

- Articles published in the newspaper of Economic Times, The Indian Express, and Business Standards.

- Published reports and surveys conducted by Deloitte, ASSOCHAM.

- Publication and circulars of Reserve Bank of India. 
- Publications of Lok Sabha and Rajya Sabha serves as the secondary source of information.

\subsection{Data analysis}

For the achievement of the objective of the study, the data compiled from various sources have been analysed and represented with the help of various charts, graphs, and tabulations and master sheets of the surveyed data. The data has been presented to analyse the pattern of banking frauds in the different states of the Indian Economy. Descriptive techniques of statistics have also been used to describe the features of data.

\subsection{Sampling design}

The data on the bank fraud collected from the 32 states of India. These 32 states 10 -year as the sample unit in this study. For the analysis of the absolute figure, the sample size has been taken as the number and amount of frauds from 2007 to 2016.

\subsection{Data Analysis and Interpretation}

This study is focused on identifying the trends of the banking frauds in the states of Indian economy in the $21^{\text {st }}$ century. For obtaining the trend of frauds data on frauds is collected and analysed from 2007-2016. Various techniques have been used to identify the trends of frauds.

\subsection{State-Wise Analysis of Frauds}

In this study, a 10 year analysis of State-wise bank frauds has been done to identify which states are most affected by the frauds. The data of the state-wise frauds has been collected 2007-08 onwards as the number of frauds and amount involved in the fraud cases is significant for study. The state-wise share of frauds in the total number of frauds is analysed. The share in frauds has been calculated on the two bases - share in the total number of fraud cases and Share in Total amount involved in fraud cases.

Share in the Total number of fraud cases is calculated as:

$$
\begin{aligned}
& \text { State's share in number of fraud }=\frac{\text { Number of frauds in State } 1^{7}}{\text { Total Number of frauds }}{ }^{8} \\
& \text { State's share in amount involved in fraud }=\frac{\text { Amount involved in frauds in State } 1^{9}}{\text { Total Amount involved in frauds }{ }^{10}} \times 100
\end{aligned}
$$


Figure 1: State-Wise Analysis of Frauds

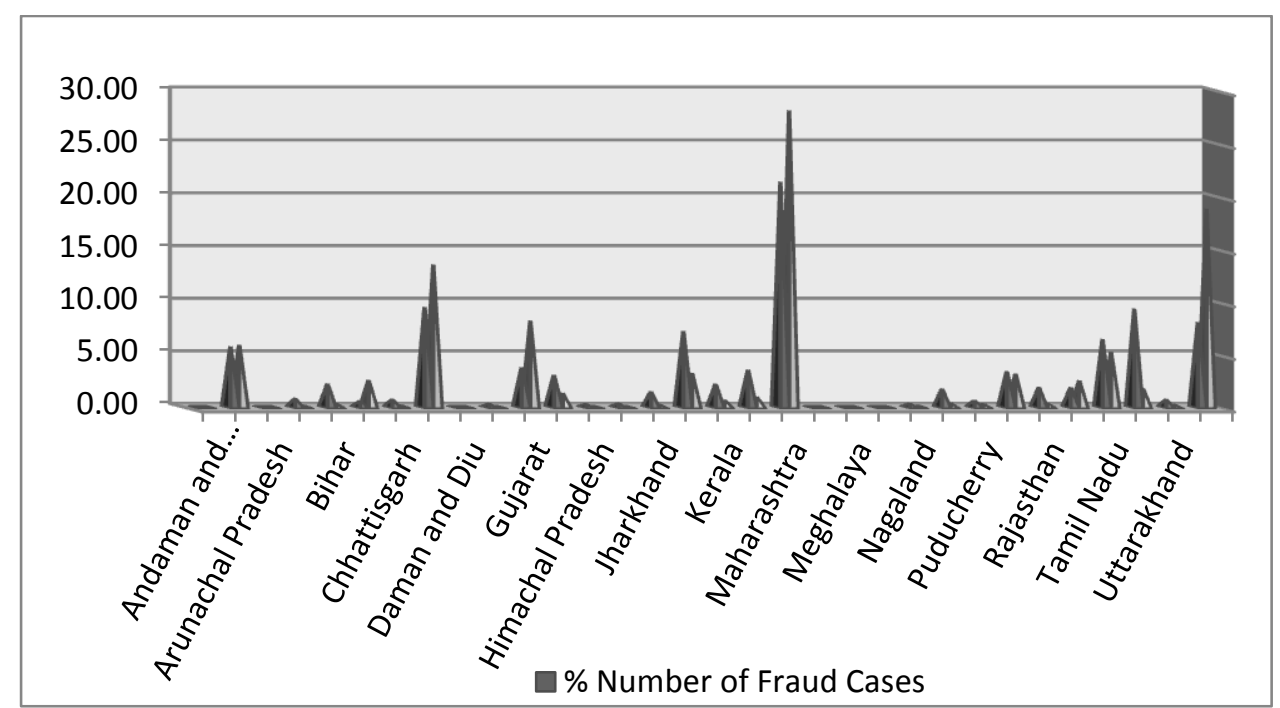

Source: Lok Sabha Unstarred Question No. 858, dated on 25.11.2011. and Lok Sabha Unstarred Question No 2129 To Be Answered On The 29 July, 2016/SRAVANA 7, 1938 (SAKA)

It is clearly depicted from the Figure 1 that the number and the amount involved in the fraud are high in 8 states and in the other states the number and the amount involved in frauds seems insignificant for study (see Table 1 for shares of all states in total number of fraud and amount involved). Andhra Pradesh, Delhi, Gujarat, Karnataka, Maharashtra, Tamil Nadu, Uttar Pradesh and West Bengal are the states with the highest share in amount and number of fraud cases.

- According to the share in total number of frauds Maharashtra is the state with the highest number of frauds $(21.48 \%)$ followed by Delhi (9.58\%), Uttar Pradesh (9.45 $\%$ ), West Bengal (8.17\%), Karnataka (7.31\%), Tamil Nadu (6.55\%), Andhra Pradesh (5.84\%) and Gujarat (3.85\%).

- According to the share in the total amount involved in the frauds Maharashtra again top the list. Highest amount involved in the frauds is found in Maharashtra (28.23\%), followed by West Bengal (18.91\%), Delhi (13\%), Gujarat (8.30\%), Andhra Pradesh (6\%), Tamil Nadu (5.32\%), Karnataka (3.32\%) and least is found in Uttar Pradesh $(1.87 \%)$.

- Then the analysis is done in accordance with the State-wise Average Amount involved in the frauds which are equally important. Another picture comes in front 
when we have calculated the average amount involved in the frauds. Chandigarh top the list of the average amount involved in the frauds with the average of $8.78 \mathrm{cr}$. per fraud case, where the share in the number of frauds was only $0.63 \%$ and in amount involved was $2.64 \%$. It shows that frauds involving the large amount were committed in Chandigarh. The results are followed by West Bengal (4.84\%), Gujarat (4.50\%) and $2.80 \%$ in Sikkim (see Table 1 to check average amount involved in frauds in all 32 states).

The average amount involved in fraud in a state is calculated as:

$$
\text { Average amount involved }=\frac{\text { Total Amount involved in frauds }}{\text { Total number of frauds }}
$$

Now, the second part of the study is directed towards identifying which state is highly affected by the frauds. The 10-year analysis of 8 states (Andhra Pradesh, Delhi, Gujarat, Karnataka, Maharashtra, Tamil Nadu, Uttar Pradesh, and West Bengal) which are significant for the study is done (derived from the first part of the study). The analysis is done in three parts. Firstly, we will identify the trend of each state's share in the total number of frauds in the last 10 years i.e. 2007-2016 (Table 2). Secondly, we will identify the trend of each state's share in total amount involved frauds and at last, we will check the trend of the average amount involved in fraud in each state.

Table 2: Year-wise State's Share in Total Number of Fraud

\begin{tabular}{|l|c|c|c|c|c|c|c|c|}
\hline \multicolumn{7}{|c|}{ Year-wise State Share in Total Number Of Fraud } \\
\hline & $\begin{array}{c}\text { Andhra } \\
\text { Pradesh }\end{array}$ & Delhi & Gujarat & Karnataka & $\begin{array}{c}\text { Maharash } \\
\text { tra }\end{array}$ & $\begin{array}{c}\text { Tamil } \\
\text { Nadu }\end{array}$ & $\begin{array}{c}\text { Uttar } \\
\text { Pradesh }\end{array}$ & $\begin{array}{c}\text { West } \\
\text { Bengal }\end{array}$ \\
\hline $2007-08$ & 6.9 & 9.0 & 3.5 & 9.3 & 24.0 & 9.7 & 9.3 & 8.6 \\
\hline $2008-09$ & 4.8 & 8.2 & 5.2 & 8.0 & 26.3 & 7.7 & 7.8 & 7.9 \\
\hline $2009-10$ & 5.7 & 9.8 & 3.2 & 8.0 & 28.2 & 7.8 & 7.9 & 6.8 \\
\hline $2010-11$ & 5.1 & 8.5 & 3.1 & 5.4 & 26.4 & 6.7 & 8.3 & 8.0 \\
\hline $2011-12$ & 5.5 & 8.9 & 3.8 & 7.6 & 26.3 & 7.9 & 8.3 & 7.8 \\
\hline $2012-13$ & 5.8 & 9.9 & 3.6 & 6.2 & 12.4 & 3.9 & 10.4 & 8.0 \\
\hline $2013-14$ & 7.3 & 11.8 & 4.1 & 4.3 & 15.1 & 5.7 & 10.8 & 8.7 \\
\hline $2014-15$ & 5.3 & 10.8 & 3.5 & 7.8 & 13.2 & 8.2 & 11.1 & 9.8 \\
\hline $2015-16$ & 6.7 & 10.6 & 4.3 & 8.8 & 13.5 & 0.1 & 12.0 & 8.2 \\
\hline
\end{tabular}

Table 2 and Figure 2 exhibit that the highest numbers of banking frauds are found in Maharashtra state but there is a change in the trend. From the year 2007-12, the 
gap between Maharashtra's share in the number of frauds and in other state's share is large but this gap starts minimizing as the number of frauds decrease in Maharashtra and increase in other states. As we can draw the results from the Table-2 that there is a significant decrease from approx. $24 \%$ in 2007 to $13.5 \%$ in $2015-16$ is seen in the Maharashtra state which is almost half (43\%) while an increase is noticed in the other state's share.

Figure 2: Year-wise State Share in Total Number of Fraud

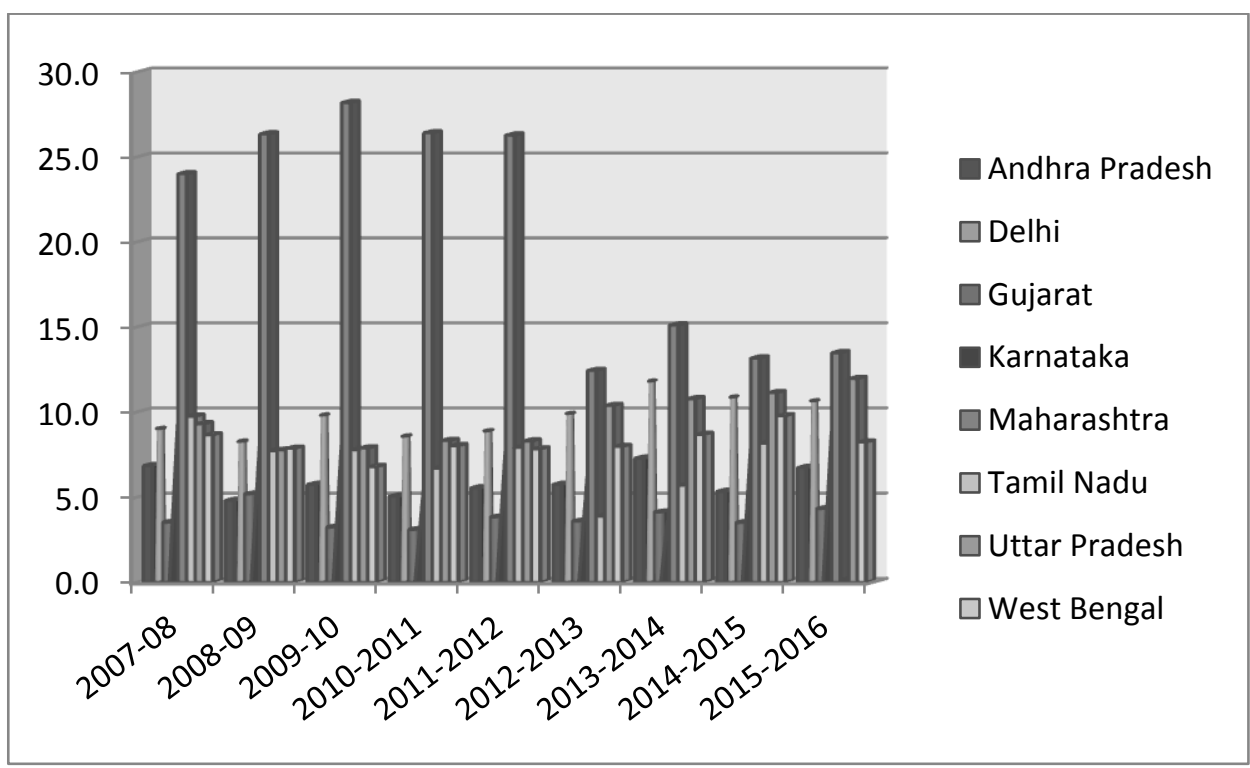

Source: Calculated by author from Table-2

After analysing the year-wise state's share in the total number of frauds, year-wise State's share in total amount involved in frauds is analysed. The results of the analysis are given in Table 3. The Table 3 and Figure 3 titled "Year-wise State's share in total amount involved" shows that in the most of the years Maharashtra has the highest share in amount involved in the frauds. On the other side, there is an increasing trend is seen in the share of other states in the total amount involved in frauds except Andhra Pradesh and Karnataka. The share of Delhi and Maharashtra in total amount involved in fraud is approximately double i.e. from $5.4 \%$ to $11.8 \%$ and $19.4 \%$ to $37.5 \%$ in the last 10 years. However, the tremendous increase is seen in Gujarat's Share i.e. from $2.3 \%$ to $11.5 \%$. 
Table 3: Year-wise State Share in Total Amount involved in Frauds

\begin{tabular}{|c|c|c|c|c|c|c|c|c|}
\hline \multicolumn{7}{|c|}{ Year-wise State Share in Total Amount Involved in Frauds } \\
\hline & $\begin{array}{c}\text { Andhra } \\
\text { Pradesh }\end{array}$ & Delhi & Gujarat & Karnataka & Maharashtra & $\begin{array}{c}\text { Tamil } \\
\text { Nadu }\end{array}$ & $\begin{array}{c}\text { Uttar } \\
\text { Pradesh }\end{array}$ & $\begin{array}{c}\text { West } \\
\text { Bengal }\end{array}$ \\
\hline $2007-08$ & 7.9 & 5.4 & 2.3 & 10.2 & 19.4 & 13.8 & 4.8 & 13.1 \\
\hline $2008-09$ & 5.0 & 11.3 & 5.9 & 5.8 & 26.9 & 8.9 & 3.1 & 13.0 \\
\hline $2009-10$ & 4.4 & 12.3 & 8.5 & 27.5 & 8.4 & 10.5 & 5.5 & 5.3 \\
\hline $2010-11$ & 5.5 & 10.0 & 12.1 & 2.2 & 25.5 & 3.1 & 2.3 & 8.8 \\
\hline $2011-12$ & 5.5 & 10.2 & 8.3 & 10.1 & 21.0 & 7.8 & 3.6 & 9.8 \\
\hline $2012-13$ & 6.1 & 14.2 & 8.3 & 2.2 & 29.4 & 4.9 & 1.6 & 20.4 \\
\hline $2013-14$ & 9.5 & 29.4 & 5.9 & 3.8 & 15.1 & 5.6 & 1.6 & 9.8 \\
\hline $2014-15$ & 5.5 & 7.0 & 7.1 & 0.8 & 29.2 & 10.6 & 1.6 & 32.8 \\
\hline $2015-16$ & 6.3 & 11.8 & 11.5 & 1.9 & 37.5 & 0.0 & 1.7 & 11.0 \\
\hline
\end{tabular}

Figure 3: Year-wise State Share in Total Amount involved in Frauds

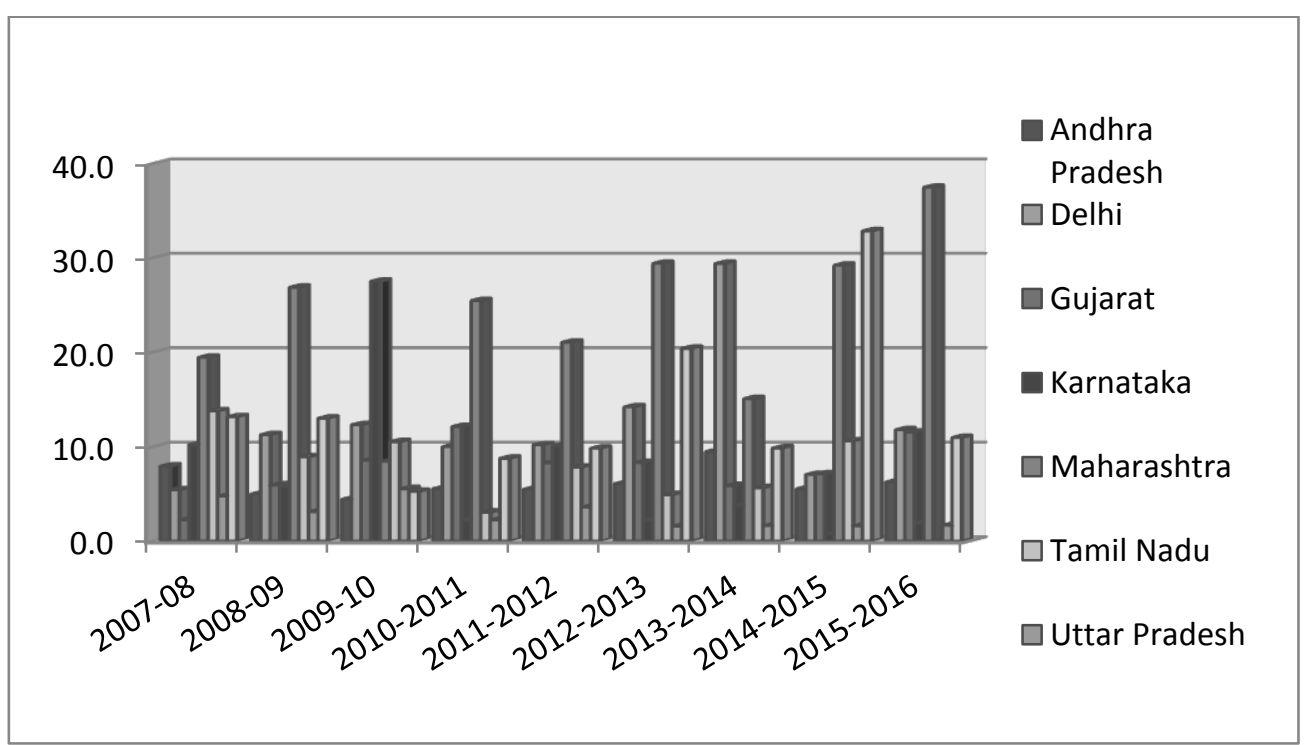

Source: Calculated by author from Table-3

After analysing the state's share in the total number and amount involved in the frauds, a year-wise analysis of average amount involved in the frauds is done. The findings are given in Table 4 . Table 4 reveals that the average amount involved in the frauds from 2007-2011 is less than 1, so Figure 4 depicts only the average amount of 
fraud involved in fraud from 2012-2016. Average amount indicates the sum of money involved per fraud ${ }^{11}$. Instead of occupying the highest share by Maharashtra in the total number and amount involved in the frauds, the average amount involved in the frauds is least in comparison to the other states which were having fewer shares in number and amount involved in fraud cases.

Table 4: Year-wise Average Amount involved in Frauds

\begin{tabular}{|l|c|c|c|c|l|l|l|l|l|}
\hline \multicolumn{10}{|c|}{ Year-wise Average Amount Involved in Frauds } \\
\hline \multicolumn{1}{|c|}{ States/UTs } & $\begin{array}{c}\mathbf{2 0 0 7 -} \\
\mathbf{0 8}\end{array}$ & $\begin{array}{c}\mathbf{2 0 0 8 -} \\
\mathbf{0 9}\end{array}$ & $\begin{array}{c}\mathbf{2 0 0 9} \\
\mathbf{- 1 0}\end{array}$ & $\begin{array}{c}\mathbf{2 0 1 0 -} \\
\mathbf{1 1}\end{array}$ & $\begin{array}{c}\mathbf{2 0 1 1 -} \\
\mathbf{1 2}\end{array}$ & $\begin{array}{c}\mathbf{2 0 1 2} \\
\mathbf{1 3}\end{array}$ & $\begin{array}{c}\mathbf{2 0 1 3 -} \\
\mathbf{1 4}\end{array}$ & $\begin{array}{c}\mathbf{2 0 1 4} \\
\mathbf{1 5}\end{array}$ & $\begin{array}{c}\mathbf{2 0 1 5}- \\
\mathbf{1 6}\end{array}$ \\
\hline Andhra Pradesh & 0.3 & 0.4 & 0.4 & 0.7 & 0.5 & 4.6 & 3.8 & 5.6 & 5.6 \\
\hline Chandigarh & 0.3 & 1.4 & 0.4 & 1.2 & 1.0 & 19.0 & 51.3 & 7.6 & 9.3 \\
\hline Delhi & 0.2 & 0.6 & 0.6 & 0.8 & 0.5 & 6.3 & 7.3 & 3.5 & 6.6 \\
\hline Gujarat & 0.2 & 0.5 & 1.2 & 2.7 & 1.0 & 10.1 & 4.2 & 11.0 & 16.0 \\
\hline Karnataka & 0.3 & 0.3 & 1.6 & 0.3 & 0.6 & 1.6 & 2.5 & 0.5 & 1.3 \\
\hline Maharashtra & 0.2 & 0.4 & 0.1 & 0.7 & 0.4 & 10.3 & 2.9 & 12.0 & 16.6 \\
\hline Punjab & 0.2 & 0.2 & 0.6 & 0.3 & 0.3 & 4.4 & 2.1 & 1.1 & 19.1 \\
\hline Tamil Nadu & 0.4 & 0.5 & 0.6 & 0.3 & 0.5 & 5.5 & 2.9 & 7.0 & 0.2 \\
\hline West Bengal & 0.4 & 0.7 & 0.4 & 0.7 & 0.6 & 11.1 & 3.3 & 18.2 & 8.0 \\
\hline
\end{tabular}

Source: Calculated by author

Figure 4: Year-wise Average Amount Involved in Frauds

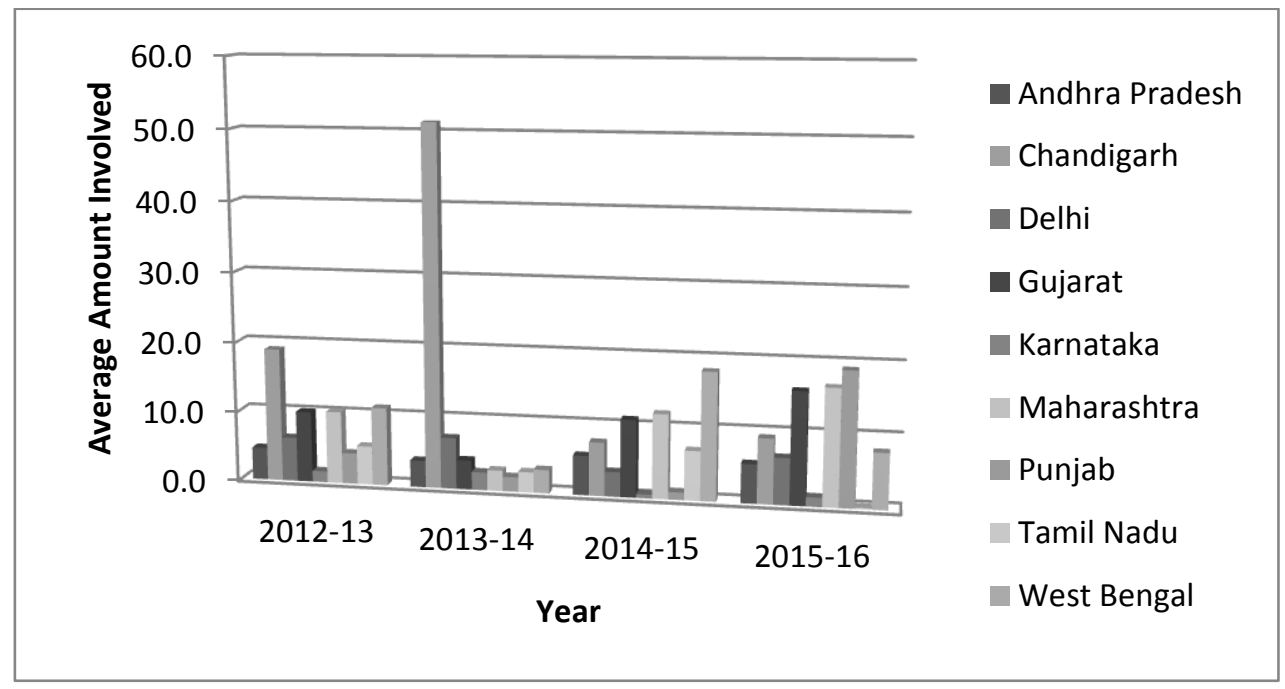

Source: Lok Sabha Unstarred Question No. 858, dated on 25.11.2011 and Lok Sabha Unstarred Question No 2129 to Be Answered On The 29 July 2016 / SRAVANA 7, 1938 (SAKA) 
On the other side Chandigarh is occupying very insignificant share in number and amount involved in fraud cases, having the highest average amount involved in fraud cases. It indicates that the frauds committed in the Chandigarh and West Bengal are the big scams. Generally, these frauds are committed by or in collusion with the internal staff/ management (Deloitte, 2015).

\subsection{Conclusion}

The global economy has witnessed that the Indian banking sector has made progressive growth in its business and profits. However, the goal of the development has been attained along with the pitfalls in the form of the increased cases of fraud in the banking sector. This unhealthy development not only leads to monetary losses to banks and victims but also affects the creditability \& goodwill of the bank negatively.

The objective of the paper is to identify the state-wise trend of bank fraud and to identify which state is most affected by the bank fraud. To achieve the objective of the study data has been collected from the various sources such as RTI, Lok Sabha and Rajya Sabha starred and un-starred questions. Descriptive techniques and the graphical presentation have been used to analyse the trend of banking fraud in various states. There is an increasing trend is found in the number and amount of the banking fraud. The results of the study are in-line with the study "Menace of Fraud in Indian Banking Industry: An Empirical study" by Bhasin (2015). By studying the State-wise trend of banking fraud the following findings have come to light:

- Despite having the largest share in the number of frauds and amount involved in frauds, Maharashtra is the least affected state of India. Although we can't exactly say why there is an increase in number of frauds. There can be many reasons behind having highest share in number and amount involved in frauds such as: i) either there can be more number of reported fraud cases in comparison to the other states. ii) or Maharashtra is the second most populated state which leads to the larger number of the banking transaction.

- Yet Chandigarh and West Bengal which are having the least number of frauds and amount involved in fraud cases but they are identified as the most affected states of India by the bank frauds. Frauds committed in the Chandigarh and West Bengal are the big scams. The expected reasons behind the frauds can be an increase in the number of cybercrime. According to the Dr. Rashmi Yadav ${ }^{12}$, DSP Cyber Cell, despite having an impressive education credit score, there has been a steady increase in the cases of fraudulent cash withdrawal from bank account per day. Customer unawareness seems to be the prime cause of the fraud. 
The Government of India and RBI is recommended to bring the strong judicial laws, cyber security laws and policy to strengthen the judicial precaution system as slow and weak judicial procedures/ prosecution provides the platform to fraudster and delay in fraud detection provides them escape route. RBI should take steps to spread Customer awareness regarding frauds. For enabling the effective investigation it is recommended that sufficient focus must be given on the "Fraud Prevention and Management Function". Bank's CEO, its Audit Committee of the Board and the Special Committee of the Board should take the personal pain to investigate the large value frauds (Bhasin, 2016). By integrating the technology for analysis with the banking procedure banks can timely detect the fraud and the banks can reduce the impact of frauds too (Kumar \& Sriganga, 2014). In future, the research can be extended to study the current picture of frauds in the most affected states of India (Maharashtra, Chandigarh, West Bengal and Gujarat).

\section{Endnotes}

1. NPCI Press Release, Statement pertaining to press reports of Debit Card compromise, dated (2016, Oct 20) retrieved from https://www.npci.org.in/sites/default/files/ Statementpertainingtopressreportsondebitcardcompromise.pdf

2. NPCI Press Release, Statement pertaining to press reports of Debit Card compromise, dated (2016, Oct 20) retrieved from https://www.npci.org.in/sites/default/files/ Statementpertainingtopressreportsondebitcardcompromise.pdf

3. Theft Act, 1978; Chapter 31, Section 16 (2), UK Laws.

4. Fraud Act, 2006; Sections 1-4, UK Laws.

5. Chartered Institute of Management Accountants, 2008; Fraud Risk Management: A guide to good practices. Available at:http://www1.cimaglobal.com/Documents/ImportedDocuments/ cid_techguide_fraud_risk_management_feb09.pdf.pdf

6. Naavi.org, Banking Frauds in India.. ICICI Bank Leads, dated (2012, Jan 9), retrieved from http://www.naavi.org/cl_editorial_12/bank_frauds_status.htm

7. Number of frauds is calculated as the sum of number of frauds in 10 years i.e. (2007-2016).

8. Total Number of frauds is calculated as the sum of number of frauds in 32 states in 10 years i.e. (2007-2016).

9. Amount involved is calculated as the sum of amount involved in the frauds in 10 years i.e. (2007-2016).

10. Total Amount involved is calculated as the sum of amount involved in the frauds in 32 years in 10 years i.e. (2007-2016).

11. Average amount involved in fraud is calculated as :

$$
\text { Average amount involved in a fraud }=\frac{\text { Amount involved in frauds }}{\text { Number of fraud }}
$$




$$
\text { (say, in } 2013-14 \text { average amount involved in Chandigarh }=\frac{820.69}{16}=51.3 \text { ) }
$$

12. Asian Voice, One fraudulent bank withdrawal each day in Chandigarh, dated 2017, Oct 25, Retrieved from https://www.asian-voice.com/News/India/North/One-fraudulent-bankwithdrawal-each-day-in-Chandigarh

\section{References}

Ahmed, I. Madawaki, M. D. \& Usman, F.(2014). Managing bank fraud and forgeries through effective control strategies: A case study of central bank of Nigeria, Gombe Branch. International Journal of Business and Management Invention, 3(4), 07-17.

Akelola, S. (2012). Frauds in the Banking industry: A case study from Kenya, (Doctoral dissertation).

Association of Certified Fraud Examiners. (2014). Report to the Nation on Occupational Fraud. Retrieved from https://www.acfe.com/rttn/docs/2014-report-to-nations.pdf .

Barnes, R.W. (1995). The Value of Quality Education to Banks And Bankers. The Journal of Indian Institute of Bankers. 66(3), 55-59.

Bhasin, M. (2015). An empirical study of frauds in the banks. European Journal of Business and Social Sciences, 4(7), 1-12.

Bhasin, M. (2016). Fraud in banking sector: Experience of developing country. Asian Journal of Social Sciences and Management Studies, 3(1), 1-9.

Chakraborty, S. (2013, September 13). Indian banking set to become fifth largest by 2020: KPMG-CII Report, Business Standard News. Retrieved from http://www.businessstandard.com/article/finance/indian-banking-set-to-become-fifth-largest-by-2020-kpmgcii-report-113091300822_1.html.

Chiezey, U., \& Onu, A. J. C. (2013). Impact of fraud and fraudulent practices on the performance of banks in Nigeria. British Journal of Arts and Social Sciences, 15(1), 1225.

Cressey, D. R. (1953). Other People's Money. Montclair, NJ: Patterson Smith, pp.1-300. 
142 | MUDRA: Journal of Finance and Accounting, Volume 4, Issue 2, Jul-Dec 2017

Deloitte Fraud Survey (2015, April 23), The Deloitte India Banking Fraud Survey Report Edition II, Press Trust of India report, Retrieved fromhttps://www2.deloitte.com/ content/dam/Deloitte/in/Documents/finance/in-fa-banking-fraud-survey-noexp.pdf.

Idolor, E. J. (2010). Bank frauds in Nigeria: Underlying cause, effects and possible remedies. African Journal of Accounting, Economics, Finance and Banking Research 6(6), 62-80.

Fagbemi, O.A. (1989). Fraud in banks: The law and the legal process. Lagos, FITC

Ganesh, A. 7 Raghurama, A. (2008). Status of training evaluation in commercial bank- a case Study. Journal of Social Sciences and Management Sciences, 37(2), 137-158.

Ghosh, S. \& Mohul (2015, March 23). Rs. 11,022 crore of fraud discovered in public sector banks between April-December 2014, Retrieved from http://trak.in/tags/business/ 2015/03/23/psu-bank-frauds-india/.

Ghosh, S., \& Bagheri, M. (2006). The Ketan Parekh fraud and supervisory lapses of the Reserve Bank of India. Journal of Finance Crime, 13(1), 107-124.

Hartmann-Wendels, T., Ma'hlmann, T. \& Versen, T. (2009). Determinants of bank's risk exposure to new account fraud- Evidence from Germany. Journal of Banking and Finance, 33(2), 37-42.

Kant, R. (2016).Frauds and money laundering in banking: Challenges in prevention and control, The Indian Banker, 4(4), 36-40.

Kaveri, V.S. (2014). Bank frauds in India: Emerging challenges. Journal of Commerce and Management Thought, 5(1), 14-26.

Khanna, A. \& Arora, B. (2009). A study to investigate the reasons for bank frauds and the implementation of preventive security controls in Indian banking industry, International Journal of Business Science and Applied Management, 4(3),1-21.

KPMG. (2008). Report India fraud Survey 2008. Retrieved from http://www.in.kpmg. com/ pdf/ FraudSurveyReport_08.pdf 
Kumar, V. B B. \& Sriganga, B.K. (2014). A review on data mining techniques to detect insider fraud in banks. International Journal of Advanced Research in Computer Science and Software Engineering, 4(12), 370-380.

Kundu, S. \& Rao, N. (2014). Reasons of banking fraud - A case of Indian public sector banks. International Journal of Information Systems Management Research \& Development . 14(1), 11-24.

Mundra, S.S. (2015). Indian banking sector: Emerging challenges and way forward. Retrieved from https://www.rbi.org.in/Scripts/BS_SpeechesView.aspx?Id=955

Nabhan, R. A., \& Hindi, N. M. (2009). Bank fraud: Perception of bankers in the State of Qatar. Academy of Banking Studies Journal , 8(1), 15-24.

Nzotta, S.M. (1999). Money, banking and finance: Theory and practice. Owerri: Intercontinental Educational publishers.

Owolabi S. A. (2010). Fraud and fraudulent practices in Nigerian Banking industry. African Research Review, 4(3b), 240-256.

Sabale, R. J. (2011). Frauds in India- Harmful Matter. Indian Streams Reserach Journal, 128-130.

Silverstone, H. \& Sheetz, M. (2004). Forensic accounting and fraud investigation for non-experts. London, John Wiley and Sons.

Singh, M. (2013). A study on the financial frauds in Indian banking sector. Intercontinental Journal of Finance resource research review, 1(9), 82-95.

Soni, R.R. \& Soni, N. (2013). An investigative study of banking cyber frauds with special reference to private and public sector banks. Research Journal of Management Sciences, 2(7), 22-27.

Willson, R. (2006). Understanding the offender/environment dynamics for computer crimes. Information Technology and people. 19(2), 170-186. 
144 | MUDRA: Journal of Finance and Accounting, Volume 4, Issue 2, Jul-Dec 2017

\section{Annexure}

Table- 1 : Table of State-wise Incidents of Frauds in Banks of India

\begin{tabular}{|c|c|c|c|c|c|c|}
\hline \multicolumn{7}{|c|}{$\begin{array}{c}\text { State-wise Incidents of Frauds in Banks of India } \\
\text { From 2007-08 to 2016-17 (up to june 2016) } \\
\text { (Rs. in Crore) }\end{array}$} \\
\hline S.No & States/UTs & $\begin{array}{l}\text { Total } \\
\text { Number of } \\
\text { Fraud cases } \\
\text { (A) }\end{array}$ & $\begin{array}{c}\text { Total } \\
\text { Amount } \\
\text { Involved }(B)\end{array}$ & $\begin{array}{l}\text { \% Number } \\
\text { of Fraud } \\
\text { Cases }(C)\end{array}$ & $\begin{array}{l}\text { \%Amount } \\
\text { Involved } \\
\text { (D) }\end{array}$ & $\begin{array}{l}\text { Avg } \\
\text { Amount } \\
\text { involved } \\
=\mathrm{B} / \mathrm{A}\end{array}$ \\
\hline 1 & $\begin{array}{l}\text { Andaman and } \\
\text { Nicobar Islands }\end{array}$ & 4 & 1.0175 & 0.01 & 0.00 & 0.254375 \\
\hline 2 & Andhra Pradesh & 1819 & 3901.0375 & 5.84 & 6.00 & 2.14460 \\
\hline 3 & Arunachal Pradesh & 29 & 19.5125 & 0.09 & 0.03 & 0.672845 \\
\hline 4 & Assam & 279 & 117.1875 & 0.90 & 0.18 & 0.420027 \\
\hline 5 & Bihar & 717 & 232.425 & 2.30 & 0.36 & 0.324163 \\
\hline 6 & Chandigarh & 196 & 1720.1375 & 0.63 & 2.64 & 8.776212 \\
\hline 7 & Chhattisgarh & 251 & 137.1625 & 0.81 & 0.21 & 0.546464 \\
\hline 8 & Delhi & 2984 & 8875.175 & 9.58 & 13.64 & 2.974254 \\
\hline 9 & Daman and Diu & 3 & 0.1925 & 0.01 & 0.00 & 0.064167 \\
\hline 10 & Goa & 111 & 27 & 0.36 & 0.04 & 0.243243 \\
\hline 11 & Gujarat & 1200 & 5398.25 & 3.85 & 8.30 & 4.498542 \\
\hline 12 & Haryana & 977 & 906.7125 & 3.14 & 1.39 & 0.928058 \\
\hline 13 & Himachal Pradesh & 104 & 29.4375 & 0.33 & 0.05 & 0.283053 \\
\hline 14 & Jammu and Kashmir & 123 & 52.7625 & 0.39 & 0.08 & 0.428963 \\
\hline 15 & Jharkhand & 484 & 165.9625 & 1.55 & 0.26 & 0.342898 \\
\hline 16 & Karnataka & 2276 & 2159.0625 & 7.31 & 3.32 & 0.948621 \\
\hline 17 & Kerala & 712 & 471.6125 & 2.29 & 0.72 & 0.662377 \\
\hline 18 & Madhya Pradesh & 1129 & 668.5 & 3.63 & 1.03 & 0.592117 \\
\hline 19 & Maharashtra & 6690 & 18367.75 & 21.48 & 28.23 & 2.745553 \\
\hline 20 & Manipur & 24 & 16.0375 & 0.08 & 0.02 & 0.668229 \\
\hline 21 & Meghalaya & 35 & 3.95 & 0.11 & 0.01 & 0.112857 \\
\hline 22 & Mizoram & 18 & 6.0625 & 0.06 & 0.01 & 0.336806 \\
\hline 23 & Nagaland & 117 & 103.0958333 & 0.38 & 0.16 & 0.881161 \\
\hline 24 & Orissa & 566 & 258.525 & 1.82 & 0.40 & 0.456758 \\
\hline 25 & Puducherry & 213 & 226.4375 & 0.68 & 0.35 & 1.063087 \\
\hline 26 & Punjab & 1087 & 2116.0625 & 3.49 & 3.25 & 1.9467 \\
\hline 27 & Rajasthan & 615 & 253.4875 & 1.97 & 0.39 & 0.412175 \\
\hline 28 & Sikkim & 606 & 1694.5375 & 1.95 & 2.60 & 2.796267 \\
\hline 29 & Tamil Nadu & 2041 & 3459.575 & 6.55 & 5.32 & 1.695039 \\
\hline 30 & Uttar Pradesh & 2942 & 1215.3375 & 9.45 & 1.87 & 0.413099 \\
\hline 31 & Uttarakhand & 248 & 162.1875 & 0.80 & 0.25 & 0.653982 \\
\hline 32 & West Bengal & 2543 & 12304.625 & 8.17 & 18.91 & 4.838626 \\
\hline & Total & 31143 & 65070.81833 & 100 & 100 & 2.08942 \\
\hline
\end{tabular}

